J-ABDIPAMAS (Jurnal Pengabdian Kepada Masyarakat)

Vol. $3 \bullet$ No. $2 \bullet 2019$

ISSN : 2581-1320 (Print) ISSN : 2581-2572 (Online)

Homepage: http://ejurnal.ikippgribojonegoro.ac.id/index.php/J-ABDIPAMAS

\title{
PROGRAM KEMITRAAN MASYARAKAT (PKM) DI SMPN 4 TAPUNG HILIR KABUPATEN KAMPAR PROVINSI RIAU
}

\author{
Leni Apriani1 ${ }^{1}$, Novri Gazali², Idawati ${ }^{3}$ \\ ${ }^{1}$ Universitas Islam Riau. Email: leniapriani@edu.uir.ac.id \\ 2Universitas Islam Riau. Email: novri.gazali@uir.ac.id \\ 3Universitas Islam Riau. Email: idawatiuir@comm.uir.ac.id
}

\begin{abstract}
This community service activity aims to provide skills to teachers and students of SMPN 4 Tapung Hilir Kampar Regency, Riau Province. The material discussed in this activity is the writing and publication of scientific papers and basic technical training in public speaking. This activity was attended by 14 teachers and 30 students. The results of this activity are (1) teachers have the ability to write scientific papers, especially in classroom action research (PTK), (2) teachers know how to publish scientific papers in National Journals, (3) teachers can use published journals for the purposes of promotion, (4) students, especially student council members and Boy Scouts have the ability to communicate well.
\end{abstract}

Keywords: Scientific Papers, Public Speaking.

\begin{abstract}
ABSTRAK
Kegiatan pengabdian kepada masyarkat ini bertujuan untuk memberikan keterampilan kepada para guru dan siswa SMPN 4 Tapung Hilir Kabupaten Kampar Provinsi Riau. Materi yang dibahas dalam kegiatan ini yaitu penulisan dan publikasi karya tulis tulis ilmiah serta pelatihan teknik dasar public speaking. Kegiatan ini diikuti oleh 14 orang guru dan 30 orang siswa. Hasil dari kegiatan ini yaitu (1) guru memiliki kemampuan dalam menulis karya ilmiah khususnya dalam penelitian tindakan kelas (PTK), (2) guru mengetahui cara mempublikasikan karya tulis ilmiah di Jurnal Nasional, (3) guru bisa menggunakan jurnal yang sudah terbit untuk keperluan kenaikan pangkat, (4) siswa khususnya anggota OSIS dan Pramuka memilki kemampuan berkomunikasi dengan baik.
\end{abstract}

Kata Kunci: Karya Tulis Ilmiah, Public Speaking.

\section{PENDAHULUAN}

SMPN 4 Tapung Hilir merupakan salah satu sekolah yang berasal dari Kecamatan Tapung Hilir Kabupaten Kampar Provinsi Riau. Sekolah ini terletak di Desa Gerbang Sari dan berjarak lebih kurang 92 KM dari Kota Pekanbaru yaitu ibu kota Provinsi Riau. Lokasi ini tidak terlalu jauh dari Kota Pekanbaru, hanya sekitar 2 jam lebih dari Universitas Islam Riau. Lingkungan SMPN 4 Kecamatan Tapung Hilir terasa sejuk, karena lingkungan sekolah masih asri dan hijau. Sekolah ini berdiri dengan SK izin operasional pada tanggal 15 September 2006. Guru di SMPN 4 Kecamatan Tapung Hilir berjumlah 14 orang, yang terbagi dari 11 orang Guru PNS dan 3 orang Guru Honor serta 4 orang Tenaga Kependidikan (tendik). 
Guru yang mengajar di sekolah, baik PNS maupun honorer merupakan ujung tombak dalam meningkatkan kualitas pendidikan. Menurut Hardiningrum (2018) Guru adalah seorang motivator, administrator, informator, instruktur dan sebagaimana dalam mendidik dan mengajar peserta didik melalui proses pembelajaran. Tugas berat dipanggul oleh guru untuk membangun generasi baru yang bermoral dan berprilaku jujur, mulia dan bermartabat demi masa depan bangsa dan negara melalui proses pendidikan. Guru akan melakukan interaksi langsung dengan peserta didik dalam pembelajaran di ruang kelas. Melalui proses belajar dan mengajar inilah berawalnya kualitas pendidikan. Artinya, secara keseluruhan kualitas pendidikan berawal dari kualitas pembelajaran yang dilaksanakan oleh guru di ruang kelas.

Peranan guru sangat menentukan dalam usaha peningkatan mutu kualitas pendidikan bangsa. Untuk itu guru sebagai komponen kunci dalam pendidikan dituntut untuk mampu menyelenggarakan proses pembelajaran dengan sebaik-baiknya untuk mewujudkan kejayaan pembangunan bangsa. Selain meningkatkan kualitas pendidikan peserta didik, guru pada zaman sekarang ini dituntut lebih profesional, lebih handal dan lebih berkompeten khususnya dalam menulis karya ilmiah. Menulis karya ilmiah sangat penting dilaksanakan oleh seorang guru, karena karya ilmiah digunakan sebagai salah satu persyaratan untuk pengembangan keprofesian guru yaitu dalam kenaikan pangkat. Berdasarkan pendapat Suhardjono dalam Siregar (2014) pengembangan profesi guru adalah kegiatan guru dalam rangka pengamalan ilmu dan pengetahuan, teknologi dan keterampilan untuk meningkatkan mutu, baik bagi proses belajar mengajar dan profesionalisme tenaga kependidikan lainnya maupun dalam rangka menghasilkan sesuatu yang bermanfaat bagi pendidikan dan kebudayaan. Selanjutnya macam-macam kegiatan pengembangan profesi guru ini terdiri dari beberapa bagian yaitu: 1) mengadakan penelitian di bidang pendidikan (PTK), 2) menemukan teknologi tepat guna di bidang pendidikan, 3) membuat alat pelajaran/peraga atau bimbingan, 4) menciptakan karya tulis, 5) mengikuti kegiatan pengembangan kurikulum (Siregar, 2014).

Berdasarkan wawancara kami dengan Bapak Agung Purwanton S.Pd yaitu Kepala Sekolah SMPN 4 Tapung Hilir, beliau mengatakan bahwa guru-guru yang mengajar di SMPN 4 Tapung Hilir termasuk beliau sendiri, belum pernah membuat karya ilmiah selama mengabdi di sekolah. Banyak faktor-faktor yang menyebabkannya, di antaranya mungkin tidak adanya workshop atau pelatihan yang membahas tentang penulisan karya ilmiah guru di Kecamatan Tapung Hilir maupun di Kabupaten Kampar. Selanjutnya mungkin disebabkan karena tidak memiliki kemampuan menulis karya ilmiah, sikap malas membaca, termakan isu penilaian karya ilmiah sulit, salah persepsi tentang bentuk karya ilmiah yang selalu dianggap sulit, motivasi yang sangat rendah, kebanyakan malas mencoba dan kesulitan dalam mempublikasikan karya ilmiahnya. Padahal Permenpan RB No. 16 Tahun 2009 tentang jabatan fungsional guru dan angka kreditnya sudah disahkan, yaitu tentang karya ilmiah merupakan unsur utama dalam penilaian angka kredit guru.

Ada beberapa macam karya tulis ilmiah, salah satunya yang cakup diminati adalah karya tulis ilmiah hasil penelitian. Dalam hal ini yang cukup diminati para guru adalah 
karya tulis ilmiah dengan menggunakan pengalaman guru sendiri yaitu dengan penelitian tindakan kelas (PTK). PTK merupakan kegiatan ilmiah yang mampu merefleksikan kegiatan pembelajaran guru yang bersangkutan melalui prosedur ilmiah dan dapat dipertanggungjawabkan dengan prosedur dan persyaratan yang bisa dilakukan seorang guru tanpa mengurangi perhatiannya pada kelas dan prestasi siswa (Ilfiandra, dkk., 2016). Menurut Nurmaini (2016) PTK dilakukan dengan tujuan untuk memperbaiki atau meningkatkan kualitas pembelajaran, dan berfokus pada kelas atau pada proses pembelajaran yang terjadi di dalam kelas. Melalui PTK guru dapat memperbaiki strategi pembelajaran yang dilakukan sehingga pembelajaran yang dilakukan lebih menyenangkan dan efektif (Nellitawati \& Aswardi, 2017).

Selain membuat karya ilmiah, Guru-guru juga dituntut untuk mempublikasikan karya ilmiahnya tersebut. Publikasi ilmiah merupakan hasil penelitian atau gagasan ilmu bidang pendidikan formal (Noorjannah, 2015). Publikasi ini dapat dimaknai sebagai upaya untuk menyebarluaskan suatu karya pemikiran seseorang atau sekelompok orang dalam bentuk laporan penelitian, makalah, buku atau artikel. Karya tulis ilmiah guru dapat dipublikasikan dalam bentuk laporan hasil penelitian atau laporan/gagasan ilmiah yang ditulis berdasar pada pengalaman dan sesuai dengan tugas pokok serta fungsi guru (Kementerian Pendidikan Nasional, Direktorat Pembinaan Pendidik dan Tenaga Kependidikan dalam Noorjannah, 2015).

Di Indonesia, kegiatan publikasi ilmiah di kalangan guru tampaknya mulai populer pada pertengahan tahun 90-an seiring dengan dikukuhkannya guru sebagai jabatan fungsional (Kepmenpan No. 84/1993). Jika ditelaah lebih dalam, Isi Keputusan Menteri ini sebenarnya telah memberikan pesan tidak langsung kepada kita bahwa pada dasarnya guru adalah seorang ilmuwan. Hal ini sejalan dengan pendapat Warsono (2017) Guru juga harus mampu menjadi ilmuwan dan intelektual dalam arti sebagai sumber ilmu, sumber pengetahuan, dan memberikan pencerahan bagi peserta didiknya.Dengan kata lain, guru berkewajiban untuk membangun tradisi dan budaya ilmiah, salah satunya dalam bentuk publikasi ilmiah. Selain tuntutan guru dalam menulis dan mempublikasikan karya ilmiah penelitian, hal yang menjadi perhatian selanjutnya adalah kemampuan dan keterampilan peserta didik SMPN 4 Tapung Hilir dalam berkomunikasi.

Permasalahan keterampilan berkomunikasi peserta didik di sekolah khususnya bagi anggota OSIS, juga telah kami tanyakan kepada Kepala Sekolah SMPN 4 Tapung Hilir. Beliau mengatakan kurang baiknya kemampuan berkomunikasi pada peserta didik secara umum dan khususnya para angggota OSIS SMPN 4 Tapung Hilir. Hal ini mungkin disebabkan tidak adanya pelajaran khusus yang diberikan kepada peserta didik maupun anggota OSIS tersebut mengenai cara berkomunikasi dan berbicara dengan benar di depan umum. Padahal Tujuan didirikannya OSIS adalah untuk melatih siswa dalam berorganisasi dengan baik dan menjalankan kegiatan sekolah yang berhubungan dengan siswa. Kegiatan yang dilaksanakan oleh OSIS di sekolah seperti melaksanakan peringatan hari besar agama islam, peringatan hari besar nasional, latihan kepemimpinan, peringatan hari jadi sekolah, masa orientasi siswa baru, latihan pidato, senam bersama, penerbitan mading dan lain-lainnya. 
Semua kegiatan yang dilaksanakan oleh anggota OSIS sangat memerlukan kemampuan berkomunikasi yang baik. Menurut Hasyim dan Irwan (2014) menyatakan ketidakmampuan berkomunikasi dapat menyebabkan seseorang tidak percaya diri ketika ia tampil di depan umum. Bagi mereka yang memiliki rasa takut untuk berbicara di depan publik, akan muncul rasa panik yang sangat mengganggu pikiran. Pada anggota OSIS biasanya akan banyak berbicara di depan umum contohnya seperti memberikan Latihan Kepemimpinan Dasar (LDK) bagi anggota OSIS yang akan bergabung. Salah satu bentuk komunikasi yang akan dibuat dengan melibatkan konsep yang benar adalah pelatihan public speaking. Public speaking adalah sebuah proses, sebuah tindakan dan seni dalam menyusun kata-kata untuk ditunjukkan di depan khalayak (Arina dalam Purnamasari, dkk., 2018).

Ketika seseorang berbicara di hadapan pemirsa (audiens) tentunya memiliki tujuan tertentu yang ingin dicapai. Untuk tujuan-tujuan tersebut, perlu mempersiapkan diri dengan sebaik-baiknya, baik yang berkaitan dengan persiapan mental, pemahaman materi yang ingin disampaikan, alat bantu yang digunakan, dan pemahaman yang baik terhadap audiens. Untuk itu diperlukan pemahaman dan pelatihan public speaking, baik ketika menjadi MC, pidato, maupun ketika mempresentasikan sesuatu. Pada kalangan peserta didik, banyak di antara mereka yang tidak mampu berbicara di hadapan orang banyak dan juga tidak mampu mengutarakan pendapat di depan kelas saat proses pembelajaran berlangsung. Hal ini disebabkan oleh kurangnya rasa percaya diri, rasa takut salah yang berlebihan sehingga takut dibuli oleh teman teman di kelas, kurangnya pemahaman terhadap materi yang ingin dibicarakan dan tidak mau berbicara dihadapan banyak orang.

Beberapa permasalah di atas baik masalah yang dihadapi oleh guru maupun peserta didik, maka diperlukan pelatihan penelitian tindakan kelas (PTK) dan publikasi karya ilmiah bagi guru serta pelatihan public speaking bagi peserta didik sebagai solusi yang ditawarkan untuk menyelesaikan masalah yang dihadapi oleh guru dan peserta didik di SMPN 4 Tapung Hilir Kabupaten Kampar Provinsi Riau. Pada pengabdian kepada masyarakat ini, skema yang diambil adalah Program Kemitraan Masyarakat (PKM). Melalui skema PKM, tim pengabdian kepada masyarakat tertarik untuk memberikan pelatihan PTK dan publikasi karya ilmiah serta public speaking dalam mengatasi masalah yang dialami oleh guru dan peserta didik di SMPN 4 Tapung Hilir Kabupaten Kampar Provinsi Riau. Adapun tujuan dilaksanakannya pengabdian kepada masyarakat ini untuk meningkatkan keterampilan dalam menulis dan mempublikasikan karya ilmiah serta meningkatkan keterampilan berkomunikasi di kalangan peserta didik.

\section{METODE PELAKSANAAN}

Kegiatan ini dilakukan dengan memberikan pembekalan ilmu dan keterampilan kepada para Guru SMPN 4 Tapung Hilir Kabupaten Kampar Provinsi Riau tentang pelatihan dan publikasi karya tulis ilmiah serta memberikan pelatihan public speaking ke pada siswa SMPN 4 Tapung Hilir Kabupaten Kampar Provinsi Riau. Kegiatan ini dilaksanakan di SMPN 4 Tapung Hilir Kabupaten Kampar Provinsi Riau dengan jumlah 
peserta 14 orang guru dan 20 orang siswa. Adapun langkah-langkah dari kegiatan ini adalah sebagai berikut:

Tahap Persiapan

Pada tahap persiapan ini tim dan 2 orang mahasiswa (Irhas Sawira dan Solihin) melakukan segala persiapan yang berkaitan dengan segala kebutuhan pelaksanaan kegiatan pengabdian kepada masyarakat di SMPN 4 Tapung Hilir Kabupaten Kampar Provinsi Riau. Adapun hal-hal yang dipersiapkan untuk pelaksanaan kegiatan ini adalah: (1) Membuat spanduk, (2) Persiapan ATK, (3) Persiapan media (laptop, proyektor, materi pelatihan), (4) Menyusun jadwal kegiatan pengabdian.

\section{Tahap Kegiatan}

Pada tahap kegiatan inilah tim pengabdian kepada masyarakat melaksanakan pelatihan yang telah dipersiapkan dengan sangat baik. Tahap ini merupakan tahap inti dari kegiatan pengabdian kepada masyarakat di SMP N 4 Tapung Hilir Kabupaten Kampar Provinsi Riau. Pada tahap ini diawali dengan pemberian materi dan meminta para guru untuk membuat penelitian tidakan kelas (PTK) hingga melakukan pendampingan dalam penelitian tindakan kelas (PTK) tersebut sebelum dipublikasikan. Serta memberikan pelatihan public speaking kepada siswa khususnya anggota OSIS dan Pramuka SMP N 4 Tapung Hilir Kabupaten Kampar Provinsi Riau. Metode yang digunakan dalam kegiatan ini yaitu metode ceramah dan praktek langsung. Adapun kegiatan yang akan dilakukan sebagai berikut:

1. Memberikan Pelatihan Teknik Penulisan Karya Tulis Ilmiah PTK

Pada langkah pertama ini tim pengabdian kepada masyarakat yang diwakilkan oleh Leni Apriani, M.Pd, Novri Gazali, M.Pd dan Aluwis, M.Pd (Tenaga Ahli bidang Metode Penelitian) memberikan pelatihan selama empat kali pertemuan tatap muka dengan format klasikal.

2. Memberikan Pelatihan Publikasi Karya Tulis Ilmiah

Pada langkah kedua ini tim pengabdian kepada masyarakat yang diwakilkan oleh Romi Cendra, M.Pd (Tenaga Ahli Relawan Jurnal Indonesia) memberikan pelatihan selama dua kali pertemuan tatap muka dengan format klasikal.

3. Memberikan Pelatihan Teknik Dasar Berkomunikasi dan Public Speaking

Pada langkah ketiga ini tim pengabdian kepada masyarakat yang diwakilkan oleh Idawati, M.I.Kom memberikan pelatihan selama dua kali pertemuan dan sejalan dengan pelaksanaan pelatihan teknik penulisan karya ilmiah PTK.

\section{Tahap Publikasi}

Pada tahap ini tim tim pengabdian kepada masyarakat melakukan pendampingan dalam melakukan penelitan tindakan kelas (PTK) hingga dengan diselesaikannya laporan penelitian berupa artikel yang disesuaikan dengan template jurnal yang mau dipublikasi. 
Tahap Evaluasi Kegiatan

Pada tahap ini tim pengabdian kepada masyarakat melakukan evaluasi dari berbagai kegiatan yang telah dilakukan. Hal ini penting dilakukan terutama bagi para tim pengabdian kepada masyarakat dan para peserta pelatihan. Kegiatan pengabdian kepada masyarakat di SMPN 4 Tapung Hilir Kabupaten Kampar Provinsi Riau ini dilakukan oleh tim. Tim ini terdiri dari seorang ketua, dua orang anggota yang berbeda keilmuan dan dua orang pakar yang diikut sertakan serta 2 orang mahasiswa. Adapun kepakaran dan tugas masing-masing adalah sebagai berikut:

Tabel 1. Kepakaran dan Tugas Masing-Masing

\begin{tabular}{clcc}
\hline No & \multicolumn{1}{c}{ Nama } & Tugas & Kepakaran \\
\hline 1 & Leni Apriani, M.Pd & Ketua & PTK \\
2 & Novri Gazali, M.Pd & Anggota & PTK dan Publikasi Jurnal \\
3 & Idawati, M.I.Kom & Anggota & Public Speaking \\
4 & Aluwis, M.Pd & Pakar & Metodologi Penelitian \\
5 & RJI Riau (Romi Cendra, M.Pd) & Pakar & Publikasi Jurnal \\
6 & Irhas Sawira & Mahasiswa & Tenaga Pembantu Kegiatan \\
7 & Solihin & Mahasiswa & Tenaga Pembantu Kegiatan \\
\hline
\end{tabular}

\section{HASIL DAN PEMBAHASAN}

Kegiatan pengabdian kepada masyarakat ini berjalan lancar. Pihak Guru SMPN 4 Tapung Hilir Kabupaten Kampar Provinsi Riau memberi sambutan dan kerja sama yang baik. Adapun rangkaian kegiatan pengabdian kepada masyarakat ini sebagai berikut:

a. Pembukaan Oleh Kepala Sekolah

Sasaran kegiatan pengabdian kepada masyarakat ini adalah guru-guru SMPN 4 Tapung Hilir Kabupaten Kampar Provinsi Riau. Acara dibuka oleh Kepala Sekolah SMPN 4 Tapung Hilir Kabupaten Kampar Provinsi Riau yaitu Bapak Agung Purwanto, S.Pd.

b. Penyampaian Materi oleh Tim Pengabdian Kepada Masyarakat

Materi yang disampaikan oleh Tim Pengabdian Kepada Masyarakat berisi tentang:

\section{Teknik Penulisan Karya Tulis Ilmiah PTK}

Pada pertemuan pertama ini tim pengabdian kepada masyarakat yang diwakilkan oleh Leni Apriani, M.Pd menjelaskan cara menentukan masalah yang akan diteliti dalam penelitian PTK ini, sehingga para guru bisa mengetahui judul apa yang mau diangkat berdasarkan permasalahan tersebut. Setelah itu menjelaskan tentang cara menulis latar belakang masalah, indentifikasi masalah, rumusan masalah, pembatasan masalah, tujuan penelitian dan manfaat penelitian dengan benar. Pada pertemuankedua, yang diwakilkan oleh Novri Gazali, M.Pd menjelaskan cara mencari referensi untuk kajian teroritis, seperti buku dan jurnal yang terbaru. Sehingga dalam penelitian yang dibuat oleh guru-guru tersebut mempunyai referensi yang baik dan terbaru. Serta mengajarkan cara pengutipan dari buku atau jurnal dan membuat daftar pustka dengan baik.Pada pertemuanketiga, diwakilkan oleh pakar di bidang metode penelitian yaitu Bapak Aluwis, M.Pd. Pada langkah ini menjelaskan tentang langkah-langkah menentukkan 
metode penelitian, siklus penelitian PTK, mengumpulkan data, menganalisis data penelitian dan menarik kesimpulan. Pada pertemuankeempat, tim pengabdian kepada masyarakat yang diwakilkanLeni Apriani, M.Pd, Novri Gazali, M.Pd dan Aluwis, M.Pd datang ke SMPN 4 Tapung Hilir Kabupaten Kampar Provinsi Riau untuk melihat proposal penelitian yang telah dibuat oleh para guru. Anggota tim pengabdian kepada masyarakat memberikan saran dan masukan sebelum guru-guru melakukan penelitian ke lapangan.

\section{Publikasi Karya Tulis Ilmiah}

Pada pertemuan kelima dan keenam, tim pengabdian kepada masyarakat yang diwakilkan oleh Romi Cendra, M.Pd (Tenaga Ahli Relawan Jurnal Indonesia) memberikan pelatihan selama dua kali pertemuan tatap muka dengan format klasikal. Adapun materi yang diberikan pada langkah ini adalah:(1) langkah-langkah dalam mencari jurnal online, (2) teknik penulisan jurnal yang layak dipublikasikan, (3) cara memasukan artikel penelitian dalam Open Journal System (OJS). Pada pertemuan ini tim menjembatani para guru untuk dipublikasikannya penelitian yang telah mereka buat tersebut, minimal dipublikasikan di tingkat nasional ber-ISSN tidak terakreditasi.

\section{Teknik Dasar Berkomunikasi dan Public Speaking}

Pada kegiatan ini berada pada pertemuan pertama dan kedua. Kegiatan ini diwakilkan oleh Idawati, M.I.Kom yang memberikan pelatihan selama dua kali pertemuan kepada anggota OSIS dan Pramuka SMPN 4 Tapung Hilir Kabupaten Kampar Provinsi Riau. Materi yang dibahas di pertemuan ini yaitu tentang: (1) penguasaan pesan, (2) teknik penyampaian, (3) teknik mengembangkan bahasan, (4) olah vokal, (5) teknik ice breaking. Siswa yang tergabung dalam anggota OSIS dan Pramuka dituntut untuk memiliki kemampuan berkomunikasi yang baik.

\section{c. Penutupan Oleh Kepala Sekolah}

Kegiatan pengabdian kepada masyarakat berjalan dengan baik dan setelah kegiatan pengabdian kepada masyarakat ini selesai, Kepala Sekolah SMPN 4 Tapung Hilir Kabupaten Kampar Provinsi Riau yaitu Bapak Agung Purwanto, S.Pd. menutup kegiatan tersebut. Kegiatan ditutup dengan acara makan-makan dan foto bersama para guru.

Dari semua kegiatan pengabdian kepada masyarakat yang sudah dilaksanakan di SMPN 4 Tapung Hilir Kabupaten Kampar Provinsi Riau, terlihat guru-guru sangat antusias dengan kegiatan ini. Guru-guru sangat tertarik dengan materi kegiatan tersebut, karena kegiatan ini membahas tentang bagaimana membuat suatu penelitian yang baik dan benar. Guru-guru juga sangat terbantu karena selain memiliki kemampuan dalam menulis karya ilmiah, dari kegiatan tersebut guru-guru juga bisa mempublikasikan karya tulis ilmiahnya sehingga bisa dijadikan sebagai bahan untuk kenaikan pangkat. 


\section{SIMPULAN}

Kegiatan pengabdian kepada masyarakat yang dilaksanakan di SMPN 4 Tapung Hilir Kabupaten Kampar Provinsi Riau memiliki banyak manfaat bagi Guru dan Siswa. adapun manfaat dari kegiatan tersebut adalah: (1) guru bisa memiliki kemampuan dalam menulis karya ilmiah khususnya dalam penelitian tindakan kelas (PTK), (2)guru bisa mengetahui cara mempublikasikan karya tulis ilmiah di Jurnal Nasional, (3) guru bisa menggunakan jurnal yang sudah terbit untuk keperluan kenaikan pangkat, (4) Siswa khususnya anggota OSIS dan Pramuka memilki kemampuan berkomunikasi dengan baik.

\section{DAFTAR RUJUKAN}

Ilfiandra, I., Suherman, U., Akhmad, S. N., Budiamin, A., \& Setiawati, S. (2016). Pelatihan dan Pendampingan Penulisan Karya Tulis Ilmiah Bagi Guru SD. Jurnal Pengabdian Pada Masyarakat, 1(1), 70-81.

Hasyim, M. dan Irwan D. W. (2014). Pelatihan Public Speaking Pada Remaja dan AnakAnak Dusun Puluhan, Desa Banyusidi, Pakis, Magelang, Jawa Tengah. Jurnal Inovasi dan Kewirausahaan, 3(2), 96-100.

Hardiningrum, I. S. (2018). Variabel-Variabel yang Mempengaruhi Kinerja Guru Sekolah Dasar Negeri di Gugus 07 Kota Kediri. Jurnal Aplikasi Administrasi, 19(2), 121-129.

Kepmenpan No. 84/1993.

Nellitawati, N. \& Aswardi, A. (2017). Efektivitas Pelatihan Metode Penelitian Tindakan Kelas Bagi Guru SD di Kecamatan Padang Timur Kota Padang. Jurnal Aplikasi IPTEK Indonesia, 1(1), 1-5.

Noorjannah, L. (2015). Pengembangan Profesionalisme Guru melalui Penulisan Karya Tulis Ilmiah Bagi Guru Profesional di SMA Negeri 1 Kauman Kabupaten Tulungagung. Jurnal Humanity, 10(1).

Nurmaini, M. Y. (2017). Implementasi Teknik Triple P Dalam Memudahkan Guru Bahasa Inggris SMA N 4, SMA N 5, Dan SMA N 8 Kota Jambi Menulis Proposal Penelitian Tindakan Kelas. Jurnal Ilmiah Universitas Batanghari Jambi, 16(1), 93-97.

Permenpan RB No. 16 Tahun 2009.

Purnamasari, D., Pratiwi, M., \& Rosalia, N. (2018). Pengembangan Public Speaking Bagi Pengurus OSIS di SMPN 30 Semarang. ABDIMASKU: JURNAL PENGABDIAN MASYARAKAT, 1(2), 63-66.

Siregar, E. (2014). Pengembangan Profesionalisme Guru Melalui Penelitian Tindakan Kelas. JURNAL Pengabdian Kepada Masyarakat, 20(77).

Warsono, W. (2017). Guru: Antara Pendidik, Profesi, dan Aktor Sosial. The Journal of Society \& Media, 1(1), 1-10. 